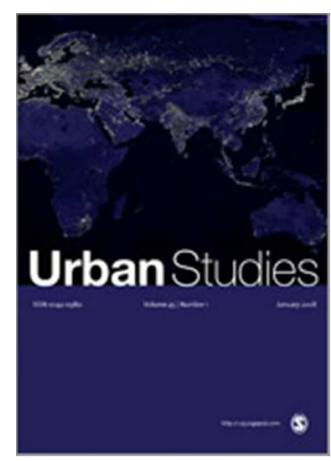

\title{
Interrogating Urban Crisis: Cities in the Governance and Contestation of Austerity
}

\begin{tabular}{|c|c|}
\hline Journal: & Urban Studies \\
\hline Manuscript ID & CUS-287-17-03 \\
\hline Manuscript Type: & Special Issue \\
\hline $\begin{array}{l}<b>\text { Discipline: Please select a } \\
\text { keyword from the following list } \\
\text { that best describes the } \\
\text { discipline used in your paper.: }\end{array}$ & Geography \\
\hline $\begin{array}{l}\text { World Region: Please select } \\
\text { the region(s) that best reflect } \\
\text { the focus of your paper. } \\
\text { Names of individual countries, } \\
\text { cities \& economic groupings } \\
\text { should appear in the title } \\
\text { where appropriate.: }\end{array}$ & Not Applicable \\
\hline $\begin{array}{l}\text { Major Topic: Please identify up } \\
\text { to two topics that best identify } \\
\text { the subject of your article.: }\end{array}$ & Other \\
\hline $\begin{array}{r}\text { Please supply a further } 5 \\
\text { relevant keywords in the fields } \\
\text { below:: }\end{array}$ & urban, crisis, governance, contestation, resistance \\
\hline
\end{tabular}

\section{SCHOLARONE \\ Manuscripts}




\title{
Interrogating Urban Crisis: Cities in the Governance and Contestation of Austerity
}

\begin{abstract}
The meaning of 'urban crisis', and its applications in concrete struggles to govern and contest austerity urbanism, remains under-specified analytically and poorly understood empirically. This paper addresses the lacuna by opening up the concept of urban crisis to critical scrutiny. It begins by exploring how urban 'crisistalk' tends to over-extend the concept in ways that can render it shallow or meaningless. The paper looks secondly at different applications of the terminology of 'crisis', disclosing key framings and problematics. In the spirit of critical urban studies, it focuses, thirdly, on practices of crisis-resistance and crisis-making. The paper concludes by summarizing the six urban crisis framings linked to six urban problematics, in order to inform future studies of austerity urbanism and assist in developing more reflexive approaches to the concept.
\end{abstract}

Keywords: urban, crisis, governance, contestation, resistance 


\section{Introduction}

In September 2013, De Montfort University in the city of Leicester, UK, hosted an Urban Studies and Urban Studies Foundation sponsored conference entitled Interrogating Urban Crisis: Governance, Contestation and Critique. This special issue is one outcome, comprising nine papers presented at the conference and a critical commentary by Professor Tim May. The special issue appears nearly a decade after perhaps the greatest shock in the history of post-war capitalism, the 2008 crash. Yet, the crash has not translated into a full-blown crisis of capitalism, or neoliberalism described by Anderson (2000: 7) as the 'most successful ideology in world history'. With the exceptions explored in the special issue (Arampatzi, 2017; Blanco and León, 2017, Watkins, 2017 - all this issue), the grip of neoliberalism seems ever-tighter, as authorities to the left and right of the political spectrum roll out more-or-less draconian austerity measures, with remarkable success in further eroding -even erasing - the legacies of post-war welfarism.

The puzzle we address is that if neoliberalism is the most successful ideology in world history, what does it mean to invoke the concept of 'crisis', urban or otherwise? As Clarke commented after the crash (2010: 342) 'the word crisis has been everywhere'. Urban scholarship, long renowned for its preoccupation with crises (Weaver, 2017 this issue), has been ever more attentive to the concept, especially in relation to austerity (Peck, 2012). Yet, there is still, as Hay (1999: 319) observed nearly 20 years ago, 'notorious imprecision' in the use of the term, particularly in light of the remarkable capacity of capitalist institutions to survive instability, tumult and crash. 
In this paper, we seek to unravel the "crisis puzzle" by problematising the concept in a way that makes it more legible, precise and applicable as a tool of analysis. The papers in the special issue explore a range of structural and constructive approaches to crisis and its antonyms through the lens of governing and contesting austerity urbanism (cf. Blanco, Griggs and Sullivan, 2014: 3136). Accordingly, we point to the need for a reflexive approach to 'urban crisis', especially in the face of normalised austerity politics. This issue is not merely of scholastic interest. The diagnosis of crisis is pivotal to grasping the potentialities for transformative urban politics.

The paper proceeds in three steps. It first captures the multiplicity of approaches to urban crisis found in the literature on cities and austerity: structure, alienation, politics, construction, conceptual limits and tipping points. It proceeds to explore studies of urban resistance through this framework, and finally reflects on the implications of the discussion for future research and introduces the special issue papers.

\section{Diagnosing Urban Crisis}

As Weaver (2017 this issue) records, the concept of urban crisis retains enormous traction, not only within Marxism (Castells, 1977; Merrifield, 2002; Boyle, 2011), but also the cultural urbanisms associated with post-structuralism (Katoaka, 2009; Beauregard, 2012) and within neoliberalism, where it is invoked against cultural pathologies and bloated public bureaucracies (e.g. Moynahan, 1965). 'Crisis' assumes a plurality of analytical guises spanning Marxism, post-structuralism, 
neoclassicism and cultural theory spanning spatial, temporal, class, racial, gendered, economic, political, democratic, environmental and security domains.

In the literatures on austerity urbanism with which we are here preoccupied, we encounter myriad crisis-imbued readings of exemplary and punitive city bankruptcies, foreclosures, racist violence and class brutalisation, particularly in the American literature (Eisinger, 2014; Davidson and Ward, 2014). US focused research on the radicalisation of the neoliberal offensive has been particularly influential in studies of austerity urbanism, perhaps contributing to the "apocalyptic' tone Angotti (2006) accused Mike Davis (2006) of in Planet of Slums. Peck (2012: 630), for example, interpreted austerity governance as the unstable relationship between state and market, leading to a "roiling' phase of neoliberal development (2012: 650) characterised by 'crisis management and instability' (Peck, 2012: 631). To the extent that austerity is normalised, it is a "state of normalcy at the very cusp of crisis' (Peck, 2012: 651).

Peck, Brenner and and Theodore (2013) stress the adaptivity and durability of variegated neoliberalism. Nevertheless, the language of crisis can seem out of place. The capitulation of Syriza in July 2015 severely damaged the Greek anti-austerity revolt (Arampatzi, 2017 this issue). At the same time, perhaps partly as a consequence of the Greek disaster, the anti-austerity surges of 2011 have not recurred with anything like the same energy or on the same scale. Part of the explanation also lies in the capacity for neoliberal variegation (Peck, Brenner and Theodore, 2013: 1091). And, as Boltanski and Chiapello (2005) revealed, this 'new spirit of capitalism' is infectious, recuperating and remaking the 1968-generation of 
militants in its own image. Such agility in the face of a disastrous crash and nearglobal revolt is the marker of a formidable hegemony, though every successful manoeuvre generates new antagonisms and unintended consequences.

The special issue attests that this is by no means the only story, but the muting of revolt and relentless advance of austerity creates a fertile climate for passivity and resentment: the former reflected in the crisis of representative democracy, the latter through the Brexit referendum and ascent to the US presidency of Donald Trump (though neither outcome should be attributed simplistically to racism). The urban determinations and counter-currents to the right wing "populist' surge remain to be properly understood, as they evolve over time. However, it is not yet clear in what sense these events herald 'crisis', as such or for whom. The crisis-potential embodied in the schism between 'globalists' and 'nationalists' should not be under-estimated, but the wisdom of hindsight warns us that neoliberal currents may adapt by re-territorialising and further radicalising market-making and workfare policies, as the UK appears set to do post-Brexit. Our question, then, is whither 'urban crisis"?

Janet Roitman's (2014) Anti-Crisis is a philosophical provocation to re-consider crisis in light of elisions she sees throughout social theory and political economy. She argues that among all the key terms in the lexicon of critical theory (such as state, capitalism and neoliberalism), 'crisis' has been the only one to escape deconstruction. She calls crisis a 'blind-spot', a 'transcendental place-holder' (2014: 94 5). This means that however the term is employed, it reifies 'contingency', in the sense that the potential for social change is pre-given in the concept. Roitman makes 
a vitally important point. A nuanced reading of 'crisis' would open the door to a better appreciation not only of how urban economies, polities and societies break down, recompose and transform, but also how political normalcy and inertia become entrenched even in the face of economic disasters, grievous suffering and heroic resistance. We elicit six crisis-framings with linked intellectual and political problematisations, to guide future research. These are structure, alienation, politics, construction, the limits of crisis and tipping points summarised in table 1 (below). We discuss each of these in turn.

\section{Structure}

Marxist perspectives on the contradictory structures of capitalist modernity remain influential, if only as background factors, in the diagnosis of urban crises. The structural proposition in Marxist thought is that as capitalism ages and globalises, it becomes prone to ever-deeper and more contagious slumps and shallower booms. It can counter these trends in various ways, by increasing rates of class exploitation and subsuming new spaces to market relations (Harvey, 2005). However, expansion becomes progressively harder to accomplish because as more of the globe is subsumed, market relations become congested, expansionary space harder to find and older capitalisms stagnate. Expressed from an agentic point of view, the Marxist claim is that for as long as human beings engage in capitalist practices these will produce structural contradictions of the kind identified by Marx, regardless of ideas, beliefs and preferences. This is why Marxists insist that capitalism should be understood as a 'system' exercising propulsive force, with both centrifugal and 
centripetal dynamics. Economic crashes are the innate property of this system (Davies, 2013).

With these or similar background assumptions, Bayırbağ and Penpecioğlu (2017 this issue) show how 'urban crisis' derives from the way structural tendencies materialize concretely and unevenly in space-time. Since the 1970s, the dominant European problematic has been de-industrialization and state rescaling, whose Spanish case is analysed by Martí-Costa and Tomàs (2017 this issue). Cities and cityregions may best be understood as 'institutional forcefields' through which contradictions are mediated, particularized, deflected and intensified (Brenner, Peck and Theodore, 2013). For Martí-Costa and Tomàs, economic crisis creates the impetus for waves of state rescaling, from which perspective the evolution of urban governance is most fruitfully interpreted. The specific contours of urban crisis in Spain after 2008 arose from the confluence of three macro-processes: the transition from Fordism to post-Fordism, reconfigurations of the welfare state and the role of urban social movements.

Parts of the special issue reads like an urban version of what Wolfgang Streeck (2017) identifies as the generalised crisis of the capitalist state in his recent Adorno Lecture: the long neoliberal transformation of post-war capitalism since the 1970s raising debt to hegemony over taxation and ushering in in what he terms the 'consolidation state' of today. Central to his argument is the changing relationship between capitalism and democracy and the advancing immunization of the former against the latter. In this context, cities are not merely 'derivative or miniature of wider societal or economic dynamics' (Zimmermann, 2012: 299). They are active 
players. Blanco and Léon point out how local and regional governments in Spain encouraged economic speculation and debt as national government set strong fiscal incentives for homeownership. This debt-fuelled economy exploded in 2008.

The devolution of responsibility from the central to the local level is also seen as a means of managing deep structural accumulation crises (Davies and Blanco, 2017). Watkins' depiction of the UK (2017 this issue) is a prime example, where 'decentralisation' means that guaranteed local state provision of services is replaced by the injunction to exercise personal responsibility in order to ease the fiscal crisis of the state. At the same time, these processes are typically hierarchical and coercive. Bayırbağ and Penpecioğlu (2017 this issue) show that in Turkey the central state plays a decisive role in economic boosterism and facilitates dispossessions by reorganising planning powers and property rights (also Bayirbağ 2010). This development has been accompanied by deepening centralization, leading to authoritarian policy regimes. Urban regeneration is 'forced marketisation' (Aalbers, 2013). The British cases further exemplify this duality, where crisis governance is characterised on the one hand by national government authoritarianism and on the other by the hollowing out of the local state welfare function and its substitution by an entrepreneurial or boosterist ethos. Thus, Fuller and West (2017 this issue) contend, Birmingham City Council sees no choice but to act as the entrepreneur.

To return again to Streeck, he argues that the 2008 crisis and its aftermath represent the exhaustion of these neoliberal strategies from the standpoint of their efficacy for capital accumulation. Yet, they continue unabated and intensified. If so, we are in a period where structural contradictions cannot be resolved without the 
eruption of crises, if at all, and all governments do is 'buy time'. Or, to put it in Marxist language, the neoliberal hegemony presides over a crisis-ridden, if not bankrupt, accumulation regime.

Bayırbağ and Penpecioğlu (2017) identify a further axis of contradiction between systemic trends and everyday (urban) life, analysed through the lens of alienation theory. To express this in Lefebvrian language, daily urban life becomes saturated by routine, repetitive and familiar practices, which contain alienation. At the same time, routines run up against contradictions or discordant experiences. For example, the promise of an open, affective networked society linked to the celebration of informational capitalism is everywhere broken in the everyday experience of atomization, stress and marginalisation among urban-dwellers, able only to view these goods from an unbridgeable distance (Davies, 2011, 2012). Critical urban studies reveal many other more-or-less fundamental axes of contradiction that vary in space-time because of the partial, uneven and contested nature of capitalist development itself. For heuristic purposes, the problematic foregrounded by structural framings of crisis is that of disclosure: what are the urban fault-lines in capitalist development in general and austerity urbanism in particular?

\author{
Alienation \\ Beyond, though linked to disclosure, is the question of translating \\ contradictions into fully articulated urban crises. This is a political problem because, \\ as Gramsci observed, structural economic crises do not in themselves generate \\ societal ruptures (1971: 184). Bayırbağ and Penpecioğlu reconsider this problem \\ through the lens of the Marxist concept of alienation. Alienation is a universal
}


property of capitalist social relations, constituted in the 'fatal schism' between 'profit-seekers ... and wage earners' (Kunkel, 2011: 9). It arises materially through dispossessing the worker of her labour power, and psychologically through the trauma separation engenders.

Bayırbağ and Penpecioğlu identify two social fields, the economic structure and urban political system, where alienation is contained through a multitude of mechanisms. For example, governance bolsters boundaries within cities. In spite of stressing network orientation and participation we observe how governance in the face of crisis has become more hierarchical (cf. Davies 2011). Though there is an apparent 'flattening' of urban governing processes as exemplified by entrepreneurial forms of urban partnership (e.g. Watkins 2017 this issue), these conceal new hierarchies, which in turn conceal power-dynamics. Against the dominant framing that 'there is no alternative' the 'expertocratic' technocracy determines who has access to governance arrangements and who does not. In the UK, the urban quangocracy insulates policies and spending decisions from public scrutiny illustration (Watkins, 2017 this issue). These are powerful containment mechanisms.

Urban crises occur, in May's sense of 'upheaval' when containment fails, as it has done repeatedly since 2008 , almost always emerging in an urban form. To borrow Lefebvrian language once again, urban political life has the propensity to breach containment mechanisms and, moreover, to pose universalizing claims: 'we, the people' (Dikeç and Swyngedouw, 2017). For Bayırbağ and Penpecioğlu, the value of this perspective on containment and breach is that it situates everyday life and system dynamics in an intelligible relationship, without reducing the one to the 
other. The framework is sensitive to urban particularities, but in a way that links them inextricably to global trends. Practically, the approach opens up the potential for comparative analysis, which they apply in discussing instances of breach in the 2008 period. From a critical urban studies perspective, alienation therefore problematizes the political economy of containment and breach. Its focal point is crisis-making: how can contradictions be politicized and revolts against austerity urbanism fomented?

\section{Politics}

The problematic of 'crisis-making' inevitably brings us to the terrain of politics, replete with warnings that the concept of 'urban crisis' must be handled deftly. Immersion for too long in the epistemic communities of urban studies might lead us to believe that the Marxisant left owns the concept of crisis. This is not the case. In the UK, Policing the Crisis (Hall et al, 1978) famously charted how confecting a moral panic around mugging allowed the right to set an 'authoritarian populist' tone, which opened up the space for it to confer blame for Britain's ills on enemies within: the unions for leaving the dead unburied, benefit 'scroungers' and foreigners for 'swamping' British culture. The right ended up 'owning' the crisis of the late 1970s, though winning battles on the ideational terrain and fomenting divisions that aided it in smashing the industrial trade unions during the 1980s (also Hay, 1999).

In the special issue, Weaver (2017 this issue) argues similarly that in the USA, the meanings attached to the term 'urban crisis' are rooted in two distinct frameworks. One, explored in previous paragraphs, locates the origin of urban crisis in structural forces and dispossessions, while another locates it in cultural 
pathologies and immorality, with highly racialised connotations. Echoing Hall et al, Weaver found that the 1970 s were crucial in securing the hegemony of cultural pathology-based conceptions of crisis, which contributed to propagating neoliberalism.

From a somewhat different perspective, May (2017 this issue) observes, 'the very idea of upheaval is regarded as core to the forward march of fundamentalist free-market ideologues'. Hinkley (2017 this issue) takes up a related theme in her study of four US cities, which identifies urban crisis governance as the purposefully disruptive strategy of neoliberal elites. She examines the experience of fiscal crisis in the four cities highlighting the narratives used by city and state government to construct urban crisis. The cause of the observed crisis, she asserts, is now attributed less to social spending, compared with previous crises, and more in terms of local governance failures, public pension commitments and global economic turmoil. In the hegemonic story-line, it is the alleged lack of political will to reduce commitments to city employees and residents that drives the crisis. Consequently, rather than developing a vision for a possible government response to a crisis-prone economy, it has become common sense to blame government, 'make tough decisions' and adapt to the new economic reality. Claims about municipal governance failure, incompetence and bloated public pension schemes are warranted by a prime directive to deliver 'fiscal responsibility'.

The scaling and re-scaling of the state is a further dimension of the 'ownership' problematic. Martí-Costa and Tomàs show how the EU was crucial in recuperating the notion of crisis and imposing the austerity regime in Spain. 
Austerity politics have been accompanied by re-centralisation at the expense of local governments, partly as a way of coping with resurgent Catalan nationalism. EU governance, and its ambiguous role as the cause and putative solution of the urban crisis, is also made explicit, unsurprisingly, in Arampatzi's account of Athens where fiscal discipline has led to an extraordinarily brutal crisis of social reproduction.

These studies reveal how easily the concept of crisis is recuperated, and hence that it should be invoked carefully. At the same time, political agency matters in crisis-construal, as Martí-Costa and Tomàs conclude in highlighting how urban social movements variegate and delimit the response. The major problematic of framing the urban crisis politically is that of the struggle for ownership: who decides what crisis this is and who is to blame? We discuss this issue further in the following section on contestation and resistance.

\section{Construction}

One of the key contributions in Roitman's (2014) critique was to disclose the subjectivities inherent in claims about crisis. As the political framing attests, to talk about urban crisis, or reject crisis-talk, is part of a struggle to produce meaning conducted through ideas, discourses and logics (Barbehön and Münch, 2017; Fuller and West, 2017 - both this issue). Interpretive comparison focuses on how 'urban crisis' attaches to specific meanings and representations in different socio-spatial contexts. Austerity urbanism does not mean the same thing, and nor does it carry the same political weight in different cities operating within ostensibly similar national and regional frameworks. Crisis-meanings are produced through local reasoning, imbued with histories, cultures and traditions. 
What becomes apparent across the special issue is how certain narratives of what the crisis means are related to specific policy responses. Rather than treating policy-making as the solution to problems, as the policy cycle implies, it seems that 'policy solutions go looking for problems' (Stone 2002: 11). Fuller and West disclose how certain constructions of crisis pave way for governance responses. They dissect how austerity programs and accompanying cuts to public services become accepted by urban governing agents, themselves 'gripped' by certain hegemonic narratives (also Davies and Blanco, 2017). In the course of this process, a dominant macroeconomic discourse gets articulated and embedded in local discourse. Crisis-talk has no necessary efficacy in articulating grievances into new 'discursive chains' capable of challenging the dominant discourse. Perhaps the contrary is also true. If 'crisis talk' reinforces despair and demoralisation, it can inhibit 'crisis making' in the sense of re-politicization. This is to suggest there is nothing necessarily energising or politicising about the language of crisis.

Barbehön and Münch apply a discourse-analytical approach in analysing media and local government textual sources, to disclose the collective imaginaries of cities; how they position themselves and make sense of their prospects post-2008. Frankfurt represents itself as a self-confident city, where crisis is exteriorised in the sense that difficulties are due to factors beyond the city's control, such as ailing Federal and State finances. Dortmund, on the other hand, portrays crisis as a visceral threat to its urban life and itself as lacking political and economic agency. Birmingham attaches crisis to the failure of leadership and institutional incompetence. Glasgow takes the opposite tack in mobilizing a spirit of 
collaboration, where the resources to overcome adversity can be found within the city itself. The problematic to which crisis-construction therefore gives rise, is subjectivity: how do the identifications and practices of actors intersect with discourses, logics and collective imaginaries in a way that produces myriad textured constructions of 'urban crisis'?

\section{The Limits of Crisis}

To re-iterate, crisis-talk does not necessarily produce upheaval. Upheaval in the sense of perpetual churn within neoliberal capitalism is 'normal', such as the breathless exhortation to change and innovate. Upheaval in the sense of revolt is not normal. The Greek term 'krisis' denotes a decisive and unexpected turning-point, where an immediate decision is made necessary (Haus and Kuhlmann, 2013: 7; Hay, 1999). What most of our authors observe is not so much dramatic change in the face of crisis but rather more of the same neoliberal remedy, step-by-step. What Hinkley (2017 this issue) argues with regard to the US holds true for most of the cases in this volume: The vision of lean government, the practices of crisis management, the taken-for-granted precariousness and focus on entrepreneurialism is 'the new normal'.

Weaver poses the pertinent question of whether crisis, understood as 'upheaval', is an appropriate vocabulary for describing this kind of routine 'suffering and plunder'. Reinforcing Fuller and West's perspective on acquiescence, he argues there is little sense that the US stands at a critical point in which elites are under assault or radical alternatives seem irresistible. For him, the notion of 'urban crisis' is of questionable value in such conditions. As Roitman (2014) also argued, the 
concept becomes analytically redundant if it applies everywhere, all the time. Crisis must therefore be differentiated from its antonyms, normality or equilibrium.

If normality or equilibrium is one antonym, another might be the notion of flourishing or vitality. Weaver (2017 this issue) explains how these ideas are mobilised by the right, through the celebration of "triumphant', 'comeback cities". 'People with means are flocking to central cities to enjoy the vibrant restaurant and entertainment scenes in districts that had formerly been abandoned after dark. Some are even spurning the suburbs to live in newly cleansed urban centres'. However, critical urban studies utilize vitality too. Arampatzi and Blanco and León (2017 this issue) both chart how insurgents build practical solidarities, prefiguring new ways of living - what Walliser (2013) called 'new urban activisms'. These practices do not disguise the privations of austerity, but downplay the notion of 'crisis' as upheaval in favour of a practical, performative politics of 'doing' and remaking the world around them (Holloway, 2010).

The framing of limits to the concept of crisis is to recognise that to be useful, there must be something outside. Gramsci's notion of 'catastrophic equilibrium' neatly captures the liminal time between 'crisis' and 'normality', describing a situation in which 'the old is dying yet the new cannot be born' and when 'a great variety of morbid symptoms appear' (Gramsci, 1971: 327). The problematisation to which this framing give rise is that of boundaries: how to position 'crisis' in relation to antonyms such as flourishing, vitality, containment, equilibrium, slow-time and normalcy. Delimiting crisis in this way helps with political diagnosis and judgment by making the phenomenon more legible: the better to recognise it, grasp its 
constructions and subjectivities, and appreciate that crisis-making is a fundamentally political struggle.

\section{Tipping Points}

Finally, urban crisis in the sense of upheaval draws attention to tipping points. Upheaval is pregnant with opportunities and threats. One scenario (as May, 2017 this issue, puts it) is the belief that the seeds of a better future are immanent in the present, the foundational premise of critique. In another scenario, hopelessness triumphs, 'absorbing its critical, transformative potential'. For example, the New Spirit of Capitalism absorbed the revolutionary energies of the 1960s, the Risorgimento those of late $19^{\text {th }}$ century Italy in a process Callinicos (2011), following Gramsci, called 'revolution-restoration'. Tipping points are strongly linked to the question of ownership.

Perhaps May's most significant point is his sense that we are moving from slow to fast-time, a notable harbinger of crisis linked to the sense discussed earlier, that the economic precariousness of the neoliberal model belies its political hegemony. He argues that the papers in the special issue point to an 'increase in the intensity of oscillations between continuity and discontinuity'. Another way of putting this might be to suggest that urban history is speeding up, with an increasing rate of disturbances within Gramsci's 'catastrophic equilibria'. From an optimist's perspective, speed-up presents the opportunity for theorists and activists to learn more quickly from past mistakes, such as how to preserve protest energies when the occupied squares are cleared and translate them into durable practices in everyday life, communities and workplaces in the next phase (Dikeç and Swyngedouw, 2017; 
Arampatzi, 2017; Blanco and León, 2017 - all this issue). Sensitivity to the everpresent dangers of recuperation, eschewing triumphalism during brief eruptions, and focusing diligently on what must be done next means according due recognition to the question of the problem of indeterminacy in urban crises.

\section{Resisting and Re-Making Urban Crises}

The objective of critical urban research is to disclose ways in which dominant framings of crisis are resisted, containment is breached and subjects politicized, to thereby cast light on how crises might be remade in a completely different way. Our aim here, on the one hand, is to point to similarities across various instances of contestation so as to provide the reader with clues about how to further examine 'politics of upheaval' around a clearly defined research agenda, and increase the effectiveness of such mobilisations. On the other hand, our heuristic (table 1) provides a lens through which to scrutinise the variations, successes and failures in mobilisations across the global landscape of urban capitalism. In this section we discuss insights developed in three papers dedicated specifically to answering the question, 'how urban crisis is contested'?

\section{The Roots of 'new urban activisms'}

As we previously suggested, when particular neoliberal governing strategies fail, authorities appear to return to or radicalise containment strategies they have already tried. The most obvious one is an active pursuit of a divide-and-rule strategy targeting the contesters, trying to co-opt leaders via a series of tactics that could be explicated with reference to Foucault's 'technologies of power'. Yet, this strategy has 
a serious defect, given the gap in everyday urban politics between what is promised and what is actually delivered (Watkins, 2017 this issue). In fact, the harm caused by economic crises is distributed 'unevenly... among socio-economic groups' (Blanco and León, 2017 this issue). Unevenness finds its spatial expression in the exceptionally heavy price paid by certain localities, like Athens or Madrid. Behind unevenness lies an economic policy promoting a growth model based on urban rent, vanity schemes and prestige developments. The resultant austerity urbanism, often intensified by debt incurred through speculation, comes to the scene as an unevenly experienced and challenged phenomenon (Davies and Blanco, 2017). Contesting urban crisis then inevitably becomes a place-based phenomenon (Arampatzi, 2017 this issue) where the role of localities and communities struggling over the meaning and ownership of crisis becomes the focus of our analysis. We address two issues here: 1) the relationship between containment strategies and contestation; and 2) how 'spatio-temporally determinate contradictions and fault-lines' translate into political responses that seek to 'own the crisis' through a repertoire of representational and organisational strategies and tactics.

One major containment strategy is that of (re)shaping the 'social capital' of activists around a 'consensus' based participatory politics, with the promise of positive re-distributional consequences. Yet, potentially negative distributional consequences (under austerity urbanism) trigger discontent on the part of community leaders. As Watkins (2017 this issue) shows, such tensions are inevitable because what is actually delivered is 'in profound contradiction, with their [the activists'] collective identities, motivations and practices' (Watkins, 2017 this issue). 
The contradictory nature of participatory containment strategies produces an unintended outcome in the form of resistance, though it may not be conceived in ideological anti-austerity terms.

Containing alienation requires that public authorities/elites have the necessary capacity to act upon the crisis. Yet, it may well be that they run out of options. Then, 'the inaction of public authorities and the incapacity of the main opposition parties ... to effectively address a crisis' (Blanco and León, 2017 this issue) opens up a space for anti-austerity forces.

In examples, such as Watkins' case study of the East Midlands, where activists are 'in touch' with the public authorities, contestation can develop if leaders retain a healthy distance, whilst engaging with them. Then, 'local participation' can backfire turning it into a source and venue for challenging hegemonic thinking. Then, politics overflows normality and containment is breached at least to a degree. The potential for crisis-making in everyday breaches may be realised, if activists foster and maintain long-term collective interests/identity/practices (within community) and retain a clear sense of separation from the state.

But how exactly can this progression occur? The clues are in the three key processes of consensus building that seek to recuperate the rebels: 'historical (an act of forgetting), spatial (physical reconstruction), and discursive (the adoption of new language and practices)' (Watkins, 2017 this issue). An effective contestation strategy can really 'flourish' when the contesters begin to design their own socioeconomic order and its territoriality even as they remain 'in touch' with the authorities, thereby adopting a "symbiotic' or 'complementary' contestation 
strategy (Arampatzi, 2017 - this issue). This approach is redolent of the old "in and against the state" perspective (London-Edinburgh Weekend Return Group, 1980). It remains to be seen what lessons those advocating such an approach today learn from their predecessors (e.g. Newman, 2012).

If we are to understand how 'spatio-temporally determinate contradictions and fault-lines' are translated into a political response capable of claiming ownership of the crisis, we need to problematize the socio-political infrastructure of contestation. Resistance may emerge spontaneously, but organised contestation does not flourish overnight. What the activists do is rather rework the infrastructure, by revitalising pre-existing networks of solidarity over time, while expanding the social base in an attempt to ignite the masses, as occurred the cases of Greece and Spain (Arampatzi, 2017; Blanco and León, 2017 - both this issue). As previously suggested, an institutionalised interface between the contesters and formal politics could well serve the ends of resistance when the time is ripe (Watkins, 2017 this issue). Neighbourhood associations that flourished in the 1970s and 1980s in Spain, for instance, seem to have constituted the socio-political infrastructure of a 'new cycle of (urban) social mobilisations in Spanish cities'. While their leaders were coopted and joined formal politics during the 1980s and 1990s, their institutionalised presence in the cities offered a fruitful ground to start this second wave of mobilisation in the 2000s (Blanco and León, 2017 this issue). Apparently, such interfaces, though unintentionally, contribute towards the historical continuity of resistance. Hence, contestation and resistance are the product of may layers of of historical experience and experimentation, where each layer arises from a particular 
period of urban crisis, recuperated or pacified by the political establishment at earlier tipping points, only to take a new form in the coming period with new discourses and political agents added to the scene. Put simply, instruments of containment can, in the right circumstances become instruments of breach.

\section{Constructing alternatives}

The construction of $21^{\text {st }}$ century alternatives to austerity and resistance is often construed in the language of 'social innovation'. For Blanco and León (2017 this issue), this term refers to 'practices that seek to satisfy basic human needs through horizontal cooperative relations between citizens'. Such acts of 'solidaritymaking' not only compensate for the lack or failure of welfare policies in the manner of neoliberal self-help. They also turn those dispossessed by crisis, including immigrants, into active political subjects. Politicisation takes ownership of the crisis by targeting caused by past policies and failed containment strategies. The pillars of this strategy to reclaim ownership of the crisis could be listed as follows:

a) Fighting dispossession (such as home repossessions) and enabling 'the satisfaction of previously alienated human needs' on the basis of alternative modes of economic conduct, while empowering the excluded/oppressed against the charitable or selfhelp ethos and the 'politics of fear' employed by authorities and right extremists (Blanco and León, 2017; Arampatzi, 2017 - both this issue);

b) Empowering those dispossessed by austerity, by challenging dominant cultural political economies, such as unbridled consumerism, rugged individualism and racism, and challenging alienation; and at the same time, seeking to bring different 
mobilisations together by encouraging them to negotiate 'differences and political antagonisms' (Blanco and León, 2017; Arampatzi, 2017; Watkins, 2017 - all this issue);

c) Pushing for a change in the political opportunity structure to create 'a more inclusive democratic governance by changing power relations between different social forces, between the civil society, state and market, and between different levels of government' (Blanco and León, 2017 this issue).

d) Pursuing an active place-making strategy weaving an inter-local/inter-scalar web of resistance among the dispossessed, tying together 'local rationalities' on the basis of national and global rationalities of solidarity. Solidarity-making 'from below' (Arampatzi, 2017 this issue), then, entails a counter-hegemonic place-making strategy, aiming to territorialise an alternative, performative, socio-economic order. If successful, this approach bypasses, or at least defers, the insurrectionary approach to transformation associated with traditional Marxist readings of crisis and revolution by cultivating flourishing and vitality in everyday urban life.

Lessons can be drawn from the analysis above. First, contestation is about values and discourses. Second, it can only ever effectively flourish only with reference to everyday life, and grows on that ground because the effects of alienation are felt deeply there. Finally, the success of 'solidarity-making' should be measured by its capacity to transform the masses into organised political agents, politically educating them around a new social ethics of co-existence such as Arampatzi's aspirational "solidarity economy". 


\section{Sustaining Urban Contestation and Resistance?}

The constitution of political agency through 'solidarity-making' is a slow process, and the three papers point to two parallel paths that prevent insurgents being co-opted. They may try to foster state-like alternative mechanisms (so as to replace the state, or to develop a model for reform when the time is ripe politically speaking); or, stay in touch with the authorities with the aim of capturing political power when the conditions are ready.

For example, while 'spontaneity and informality' could be seen as 'organisational characteristics of emergent urban solidarity spaces' (Arampatzi, 2017 this issue) where an alternative logic of (self)-rule/ public administration is developed, the key challenge is the capacity of insurgents to institutionalise this 'alternative order'. Yet, it may be that 'the new cannot be born', not only because the elite succeeds in recuperating system antagonists, but also because not every activist has, or wants, a clear strategic blueprint for action (Watkins, 2017 this issue). Their strategies are always in the making and orientations tend to remain informal among those taking an anti-institutional approach (Arampatzi, 2017 this issue).

Informality functions as an obstacle in other ways, too. Arampatzi (2017, this issue) draws our attention to 'uneven power relations' among different initiatives to emphasise the 'limitations of horizontalism'. Some groups gain undue weight in emergent networks of solidarity, such as the recuperation of key elements of the Greek resistance into the now mainstream austerity party, Syriza. In this context, the informal nature of solidarity networks tends to mask hierarchies, which are easier to 
recognise in formal politics. Arguably, a comparative categorisation of networks (and groups) of contestation would be useful from this standpoint.

What conclusions might we then draw about enhancing the sustainability of contestation? First, urban scholar-activists must continue systematically to examine and document the strategies developed in different cases in different geographies in order to inform others, while discussing how different experiences might translate into a more general plan for social change. In this sense, critical urban studies must be a contribution to answering the political question of how ownership of the crisis can be taken from the right. Relatedly, this involves developing an awareness of the dangers represented by divisive discourses and reactionary forms of 'solidaritymaking', such as the Greek-only food banks of Golden Dawn (Arampatzi, 2017 this issue). We urgently need to understand what it takes for anti-capitalist interpretations of the crisis to grip and make sense at the grassroots.

Second, pursuing an active scalar strategy of representation and organisation strengthens contestation by establishing ties across insurgents of different backgrounds and among political actors at various levels. An important benefit of this strategy is that it increases the technological capacity of resistance, in the Foucauldian sense. In other words, it facilitates the transfer of know-how to activists lacking the capacity or the will to institutionalise their movement. Third, experimenting with combinations of hierarchical and horizontal forms of political organisation strikes a necessary balance between 'the formal' and 'the informal'. It is perhaps the right time to consider Matrix style organisations in politics. 


\section{Conclusions}

The special issue can be read as a contribution to developing a better understanding of how urban crises are constituted, politicised, recuperated and mediated through practices of governance and contestation. We have sought to make legible the multiple ways in which our contributors apply the concept of crisis to cast new light on the contours of austerity urbanism and its antagonists. Table 1 summarises the six main crisis framings and problematics we disclose in the paper. We hope the simple heuristic will be a useful device for urban scholars attempting to develop a better appreciation of the crisis-puzzle we identified at the beginning.

\begin{tabular}{|l|l|}
\hline Crisis Framing & Problematic \\
\hline Structure & $\begin{array}{l}\text { Disclosing spatio-temporally determinate } \\
\text { contradictions and fault-lines. }\end{array}$ \\
\hline Alienation & Containment and crisis-making \\
\hline Politics & Owning the crisis \\
\hline Construction & $\begin{array}{l}\text { Subjectivity: meaning-making through discourse, } \\
\text { logic and identificatory practices. }\end{array}$ \\
\hline Boundaries & $\begin{array}{l}\text { Delimiting the crisis. Crisis and antonyms: e.g. } \\
\text { equilibrium, normality, flourishing, solidarity- } \\
\text { making }\end{array}$ \\
\hline Indeterminacy & $\begin{array}{l}\text { Tipping points: between rupture and } \\
\text { recuperation }\end{array}$ \\
\hline
\end{tabular}

\section{Table 1: Urban Crisis Framings and Problematics}

Many of our contributions reinforce the view that, far from provoking fully politicised crises, austerian normality reigns. They are are imbued with a degree of pessimism far removed from the recent surge in hopes for salvation invested in cities and urban political actors during the upsurge of 2011 (Mason, 2012; Merrifield, 2011). From this perspective, as May intuits, we are witnessing waves of political 
and economic crisis, followed by waves of renewed hegemony. However, he also sees the potential for new waves of upheaval following quickly behind. As we argued earlier, this pattern suggests that formidable as the neoliberal hegemony may seem, ruling elites are capable only of returning to or radicalizing governance strategies they, and we, already know and that new periods of containment may therefore be fragile. Talk of neoliberal "innovation" is increasingly banal. In this scenario, the structural perspective identifies a proliferation of 'morbid symptoms' within a 'catastrophic equilibrium', suggesting that further tipping points will soon arise with indeterminate possibilities and consequences. It depends on who gets to own the crisis.

In the context of the current authoritarian backlash against neoliberal globalism, this diagnosis makes it all the more urgent for urban activists to develop credible alternatives. The crucial from our studies of contestation are threefold. First, scholar activists must interrogate the politics of mobilization to document them and inform what happens next. A vital task of critical urban studies is to join the battle to prevent further periods of recuperation and restoration. Part of this role is to encourage activists to reflect on failure and be reflexive on the containment strategies to which they are subject, as well as on the sources of their agency and political power. Second, resistance is much more effective when it scales outward and upward. The Spanish case has very important lessons for others in this regard about the possibility of replication or emulation. Third, we find that working "in and against" the state remains an important tactic (if not strategy) for activists and that spaces of alienation containment can morph into spaces of breach. Relatedly, formal and informal, hierarchical and horizontal modes of contestation 
are inextricably linked. While opting for one approach or the other is a real tactical dilemma, at the level of theory and strategy the one rarely exists without the other.

The special issue also shows that for every generalisation, there are local specificities that make subsumptive accounts redundant. Writing on local political capacities in the face of the global financial crisis, for example, Georgios Terizakis (2017), shows how the crisis of late capitalist democracies occlude much older crises of household reproduction. Cities in similar circumstances differ in their responses to multi-layered crises. Moreover, retrenchment imposed by higher levels of government do not mean that cities have no choices at all, even if they are not good ones. Even the Greek 'one-size-fits-all' approach to retrenchment leaves 'windows of opportunity' for local leaders, employing different arguments and policy styles to influence - or fail to influence - the legitimacy of austerity in their cities (cf. Stolzenberg et al. 2016). The space for locally determined action is equally apparent in the differing governance strategies of cities in Britain, Germany and the US. Such locality factors make comparative accounts of how variegated urban crises are made, governed and contested, both interesting and vitally important (Barbehön and Münch, 2016). This is true even where cities appear weak by comparison with regional and national actors. Urban political agency and struggles for ownership over the meaning of crisis, structurally determined or otherwise, are key determinants of how tipping points lead respectively to rupture, flourishing or recuperation.

The special issues proceeds in the following order. The first section, with four analytical framework papers begins with Weaver's historicization of urban crisis, 
followed by Bayırbağ and Penpecioğlu's analysis of alienation, containment and breach. To end the first section, Barbehön and Münch develop their analysis of locally distinctive crisis discourses, and Fuller and West focus discuss the subjectivities and identificatory practices that produce acquiescence to austerity. The second section consists of two papers on 'governing' the urban crisis. It begins with Martí-Costa and Tomàs's historical analysis of the Spanish transition from Francoism, through democratisation and restructuring to austerity and concludes with Hinkley's analysis of how narratives of fiscal crisis in the US are applied in cities to render austerity governable. The third section consists of three distinctive papers exploring the contestation of austerity urbanism. First, Heather Watkins explores pushback against dominant third-way conceptions of community organising. Arampatzi then develops her account of solidarity-making amidst the most brutal forms of crisis and austerity in Athens, complemented thirdly by Blanco and León's analysis of how innovative neighbourhood solidarities are inter-woven with largerscale social movements. Finally, Tim May concludes with critical thoughts about the subject of the collection, and the means by which the seemingly permanent oscillation between crises, resistance and recuperation might lead to a more permanent and just resolution. 


\section{Acknowledgements}

We are grateful to the Urban Studies Journal and the Urban Studies Foundation for sponsoring the conference as the contributions to this collection mainly came from papers presented there. Ruth Harkin and Danny MacKinnon deserve our special thanks for their support in putting together the special issue. We are also grateful to the reviewers for their substantial contribution to improving the quality of articles you are about to read.

\section{References}

Aalbers MB (2013) Neoliberalism is Dead . Long live Neoliberalism! International Journal of Urban and Regional Research 37(3): 1083-1090.

Anderson P (2000) Renewals. New Left Review 1: 1-20.

Angotti T (2006) Apocalyptic Anti-urbanism: Mike Davis and his Planet of Slums, International Journal of Urban and Regional Research 30(4): 961-967.

Arampatzi A (2017) The spatiality of counter-austerity politics in Athens, Greece:

Emergent 'urban solidarity spaces'. Urban Studies 54(9): DOI:

$10.1177 / 0042098016629311$. 
Barbehön M and Münch S (2016) The 'distinctiveness of cities' and distinctions in cities: boundaries of belonging in comparative perspective. Urban Research \& Practice 9(1): 37-55.

Barbehön M and Münch S (2017) Interrogating the city: Comparing locally distinct crisis discourses. Urban Studies 54(9): DOI: 10.1177/0042098015613002.

Bayirbağ M K (2010) Local Entrepreneurialism and State Rescaling in Turkey. Urban Studies 47(2): 363-385.

Barber B (2013) If Mayors Ruled the World. Dysfunctional Nations - Rising Cities. New Haven, London: Yale University Press.

Bayırbağ MK and Penpecioğlu M (2017) Urban crisis: 'Limits to governance of alienation'. Urban Studies 54(9): DOI: 10.1177/0042098015617079.

Beauregard, R (2012) 'What Theorists Do', Urban Geography, 33(4): 474-487.

Bevir M and Rhodes RAW (2010) The State as Cultural Practice. Oxford: Oxford University Press. 
Blanco I and León M (2017) Social innovation, reciprocity and contentious politics:

Facing the socio-urban crisis in Ciutat Meridiana, Barcelona. Urban Studies 54(9):

DOI: $10.1177 / 0042098016659044$.

Blanco I, Griggs S and Sullivan H (2014) Situating the local in the neoliberalisation and transformation of urban governance. Urban Studies 51(15): 3129-3146.

Boltanski L and Chiapello E (2005) The New Spirit of Capitalism. London: Verso.

Boyle, M (2011) Commentary. The New Urban Politics Thesis: Ruminations on MacLeod and Jones' Six Analytical Pathways, Urban Studies, 48(12): 2673-2685.

Callinicos A (2012) Contradictions of austerity. Cambridge Journal of Economics 36(1): 65-77.

Castells, M (1977) The Urban Question: A Marxist Approach. London: Edward Arnold.

Chakrabarti V (2013) A Country of Cities. A Manifesto for an Urban America. New York: Metropolis Books. 
Clarke J (2010) Of Crises and Conjunctures: The Problem of the Present. Journal of Communication Inquiry, 34(4): 337-354.

Davidson M and Ward K (2014) ,Picking up the pieces': Austerity urbanism, California and fiscal crisis. Cambridge Journal of Regions, Economy and Society 7: 81-97.

Davies JS (2011) Challenging Governance Theory: From Networks to Hegemony. Bristol: Policy Press.

Davies JS (2012) Network Governance Theory: A Gramscian Critique. Environment and Planning A 44(11): 2687-2704.

Davies JS (2013) Just do it differently? Everyday making, Marxism and the struggle against neoliberalism. Policy \& Politics 41(4): 497-513.

Davies J S and Blanco I (2017) Austerity Urbanism: Patterns of Neoliberalisation and Resistance in Six Cities of Spain and the UK". Environment and Planning A, forthcoming. 
Davis, M. 2006. Planet of Slums. London: Verso.

Dikeç M and Swyngedouw E (2017) Theorizing the politicizing city. International Journal of Urban and Regional Research. Epub ahead of print 29 January 2017. DOI:

10.1111/1468-2427.12388.

Eisinger P (2014) Is Detroit Dead? Journal of Urban Affairs, 31(1): 1-12.

Fuller C and West K (2017) The possibilities and limits of political contestation in times of 'urban austerity'. Urban Studies 54(9): DOI:10.1177/0042098016651568.

Gibson-Graham JK (2006) A Post-Capitalist Politic, MN: University of Minnesota Press.

Gramsci A. (1971) Selections from Prison Notebooks. London: Lawrence \& Wishart. Translated and edited by Quintin Hoare and Geoffrey Nowell-Smith.

Hall S, Critcher C, Jefferson T, Clarke J and Roberts J (1978) Policing the Crisis:

Mugging the State and Law'n'Order. London: Macmillan. 
Harvey D (2005) A Brief History of Neoliberalism, Oxford: Oxford University Press.

Haus M and Kuhlmann S (2013) Lokale Politik und Verwaltung im Zeichen der Krise? In: Haus M and Kuhlmann S (eds) Lokale Politik und Verwaltung im Zeichen der Krise? Wiesbaden: Springer VS, pp.7-24.

Hay C (1999) Crisis and the Structural Transformation of the State: Interrogating the Process of Change. British Journal of Politics and International Relations, 1(3): 317344.

Hinkley S (2017) Structurally adjusting: Narratives of fiscal crisis in four US cities. Urban Studies 54(9): DOI: 10.1177/0042098015618167.

Holloway J. (2010) Crack Capitalism. London: Pluto Books.

Katoaka S (2009) 'Posty Urban Political Theory', in Davies JS and Imbroscio DL (eds) Theories of Urban Politics, London: Sage, pp. 73-88. 2nd edition. 
Katz B and Bradley J (2014) The Metropolitan Revolution: How Cities and Metros Are

Fixing Our Broken Politics and Fragile Economy. Washington, DC: Brookings Institution Press.

Kunkel B (2011) How Much is Too Much. London Review of Books, 33(3): 9-14.

London-Edinburgh Weekend Return Group (1980) In and Against the State. London: Pluto Press.

Martí-Costa M and Tomàs M (2017) Urban governance in Spain: From democratic transition to austerity policies. Urban Studies 54(9): DOI:

$10.1177 / 0042098016669452$.

Mason P (2012) Why it's Kicking off Everywhere: The New Global Revolutions. London:Verso.

May T (2017) Urban Crisis: Bonfire of Vanities to find Opportunities in the Ashes. Urban Studies 54(9): forthcoming.

Merrifield A (2002) Metromarxism: A Tale of the City. London: Routledge. 
Newman J (2012) Working the Spaces of Power: Activism, Neoliberalism and Gendered Labour. London: Bloomsbury.

Moynihan DP (1965) The Negro Family: The Case for National Action. Washington, DC: Office of Policy Planning and Research, U.S. Department Of Labor.

Peck J (2012) Austerity urbanism: American cities under extreme economy. City 16(6): 626-655.

Peck J, Theodore N, and Brenner N (2013) Neoliberal Urbanism Redux? International Journal of Urban and Regional Research, 37(3): 1091-1099.

Roitman J (2014) Anti-Crisis. Durham, NC: Duke University Press.

Stolzenberg P, Terizakis G, Hlepas N and Getimis P (2016) Cities in Times of Crisis.

Fiscal Consolidation in Germany and Greece. Baden-Baden: Nomos. 
Stone DA (2002) Policy paradox: the art of political decision making. New York: Norton.

Streeck W (2017) Buying Time: The Delayed Crisis of Democratic Capitalism. Second edition with a new preface. London/New York: Verso.

Terizakis G (2017) Städtische Handlungsmöglichkeiten unter den Bedingungen der Finanzkrise im deutsch-griechischen Vergleich am Beispiel der Kultur- und Sozialpolitik in Patras und Wuppertal. In Barbehön M and Münch S (eds): Variationen des Städtischen - Variationen lokaler Politik. Wiesbaden: Springer VS, pp. 299-326.

Walliser A (2013) New urban activisms in Spain: Reclaiming public space in the face of the crises. Policy and Politics 41(3): 329-350.

Watkins HM (2017) Beyond sweat equity: Community organising beyond the Third Way. Urban Studies 54(9): DOI: 10.1177/0042098016651552.

Weaver T (2017) Urban crisis: The genealogy of a Concept. Urban Studies 54(9): DOI: $10.1177 / 0042098016640487$. 


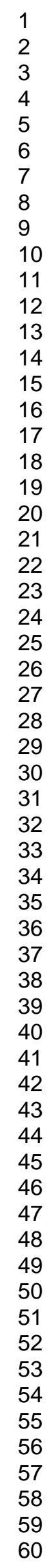

Zimmermann K (2012) Eigenlogik of cities - Introduction to the themed section.

Urban Research \& Practice 5(3): 299-302. 